\title{
ANALISIS KOMPARASI METODE PREDIKSI PENDAPATAN OPERASIONAL PADA KELOMPOK KEGIATAN USAHA BANK PERKREDITAN RAKYAT DI JAWA TIMUR
}

\author{
Zainul Hidayat ${ }^{1)}$, Jesi Irwanto ${ }^{2)}$ \\ ${ }^{1)}$ Zainul Hidayat, Manajemen, STIE Widya Gama Lumajang \\ Email : zd4y4t@gmail.com \\ ${ }^{2)}$ Jesi Irwanto, Manajemen, STIE Widya Gama Lumajang \\ Email : irawanjasy21@gmail.com
}

\begin{abstract}
Abstrak
Kegiatan perbankan bertujuan untuk meraih laba yang optimal, salah satunya melalui pendapatan operasional. Setiap tahun perbankan diwajibkan untuk menyusun rencana anggaran, oleh karena itu bank perlu mengetahui prediksi pendapatan operaisonal yang akurat. Penelitian ini bertujuan membandingkan hasil analisis prediksi pendapatan operasional menggunakan metode product moment, least square dan semi average, serta menentukan metode yang memiliki ketepatan prediksi pendapatan operasional yang akurat pada kelompok kegiatan usaha BPR di Jawa Timur. Sampel penelitian terdiri dari 4 (empat) BPR kategori kegiatan usaha 1 dan 4 (empat) BPR kategori kegiatan usaha 2. Perhitungan dilakukan pada masing-masing BPR dengan menggunakan 3 (tiga) metode prediksi memberikan hasil yang berbeda. Metode prediksi yang akurat digunakan memprediksi pendapatan operasional BPR kategori kegiatan usaha 1 adalah metode least square, sedangkan pada BPR kategori kegiatan usaha 2 maka metode prediksi yang akurat untuk memprediksi pendapatan operasional adalah metode product moment. Secara keseluruhan metode least square dan metode product moment merupakan metode yang akurat memprediksi pendapatan operasional pada BPR. Metode prediksi pendapatan operasional pada setiap BPR akan berbeda karena itu tergantung pada karakter dan kegiatan bank bersangkutan. Oleh karena itu bagi peneliti selanjutnya disarankan untuk melakukan penelitian dengan obyek penelitian yang lebih luas.
\end{abstract}

\section{Kata kunci : Pendapatan Operasional, Least Square, Product Moment, Semi Avarage. PENDAHULUAN}

"Ramalan penjualan adalah suatu teknik proyeksi tentang tingkat permintaan konsumen potensial pada suatu periode tertentu dengan menggunakan berbagai asumsi tertentu" (Sri Rahayu dan Andry Arifian Rachman, 2013:32). Atau juga bisa diartikan sebagai cara untuk mengukur atau menaksir kondisi bisnis di masa yang akan datang. Prediksi atau ramalan (forecast) selalu bertujuan agar ramalan yang dihasilkan mampu meminimumkan pengaruh ketidakpastian yang dihadapi perusahaan. Kegiatan ramalan (forecast) adalah meramalkan sesuatu yang bakal terjadi di masa yang akan datang. Dengan demikian ramalan harus dipandang sebagai salah satu masukan dalam pembuatan rencana. Prediksi penjualan sangat penting karena dapat mempengaruhi manajer dalam membuat perencanaan penjualan. Dalam rencana penjualan, dimasukkan keputusan manajemen berdasarkan hasil prediksi atau ramalan, masukkan lainnya, ataupun kebijakan manajemen lainnya. Untuk melakukan ramalan masa depan, teknik ramalan penjualan ada dua metode yaitu metode kualitatif dan metode kuantitatif. "Metode kualitatif merupakan suatu teknik proyeksi penjualan yang didasarkan atas pendirian atau sikap, kepercayaan atau keyakinan, perasaan, pengalaman, dan intuisi manajer sehingga hal ini benar bersifat subjektif" (Sri Rahayu dan Andry Arifian Rachaman, 2013:32). Sedangkan "metode kuantitatif merupakan cara penaksiran penjualan menggunakan model matematik (statistik) sehingga lebih objektif" (Sri Rahayu dan Andry Arifian Rachaman, 2013:32). "Metode kuantitatif terdiri dari empat metode yaitu metode trend bebas (free hand method), metode setengah rata-rata (semi average method), metode trend moment (moment trend method) dan metode kuadrat terkecil (least square method)" (Sri Rahayu dan Andry Arifian Rachman, 2013:32Beberapa penelitian dengan topik metode forecasting sales telah dilakukan, diantaranya penelitian yang dilakukan oleh Citra Paramita tahun (2011) dengan judul analisis perbandingan bahan bakar minyak dengan Standar Kesalahan Peramalan (SKP) pada PT Pertamina (persero) region IV Jateng dan DIY bahwa metode peramalan penjualan BBM yang tepat untuk Premium adalah menggunakan trend kuadratik, sedangkan untuk pertamax menggunakan trend least square. Hasil penelitian internasional oleh Asli Aksoy and Nursel Ozturk (2012) dengan judul A decision support system for demand forecasting in the clothing industry menunjukkan bahwa peramalan permintaan berbasis ANFISS sistem dapat 
membantu produsen pakaian untuk meramalkan kebutuhan lebih akurat, efektif dan sederhana metodologi yang digunakan adalah sistem Fuzzy inferensi berdasarkan adaptif jaringan ANFISS adalah digunakan untuk meramalkan permintaan di industri pakaian. Peneliti lain yaitu R. Farnoosh, P. Nabati and A. Hajirajabi (2012) dengan judul Parameters estimation for RL electrical circuits based on least square and bayesian approach menunjukkan bahwa rumus eksplisit untuk estimator least square yang berasal dan konsistensi yang kuatresistensi estimor diverifikasi ketika indukator adalah parementer yang di ketahui, estimasi maka bayesian dari parameter diatur dengan menggunakan rantai markov metode monte carlo. Industri perbankan terutama Bank Perkreditan Rakyat menarik untuk diteliti perkembangan penjualan kreditnya, karena jenis bank yang satu ini cukup unik dengan segala pendekatannya kepada masyarakat. Bank Perkreditan Rakyat di Jawa Timur akan menjadi obyek dalam penelitian ini karena indikator kinerja utama BPR di Jawa Timur pada periode Oktober 2015 sampai dengan Maret 2016 secara umum tetap menunjukkan pertumbuhan yang cukup tinggi.Tercatat total aset BPR di Jawa Timur pada periode laporan tumbuh sebesar 3,42\%, lebih tinggi dibandingkan periode sebelumnya.Penghimpunan dana pihak ketiga tumbuh sebesar 1,48\% pada periode laporan, lebih tinggi dibandingkan periode sebelumnya. Penyaluran kredit BPR di Jawa Timur tumbuh sebesar 1,29\% lebih tinggi dibandingkan periode sebelumnya.Berdasarkan data, penelitian terdahulu dan fenomena yang terjadi pada Bank Perkreditan Rakyat di Jawa Timur serta keinginan peneliti untuk membandingkan beberapa metode dalam memprediksi penjualan kredit, maka penelitian berjudul "Komparasi Ketepatan Prediksi Penjualan Kredit Pada Berbagai Variasi Ukuran Bank Perkreditan Rakyat di Jawa Timur."

Berdasarkan penjelasan di atas, maka perumusan masalah dalam penelitian ini sebagai berikut:

a)Bagaimana hasil analisis prediksi pendapatan operasional dengan menggunakan metode product moment, least square dan semi average pada kelompok kegiatan usaha Bank Perkreditan Rakyat di Jawa Timur?. b) Apakah terdapat perbedaan ketepatan hasil prediksi pendapatan operasional antara metode product moment, least square dan semi average pada kelompok kegiatan usaha Bank Perkreditan Rakyat di Jawa Timur?.c)Diantara metode product moment, least square dan semi average yang manakah memiliki ketepatan prediksi pendapatan operasional paling akurat pada kelompok kegiatan usaha Bank Perkreditan Rakyat di Jawa Timur?

\section{METODE PENELITIAN}

Penelitian ini merupakan penelitian komparatif, dimana penelitian komparatif adalah penelitian yang bersifat membandingkan. Penelitian ini dilakukan untuk membandingkan persamaan dan perbedaan dua atau lebih fakta dan sifat objek yang diteliti berdasarkan kerangka pemikiran tersebut. Rumusan masalah komparatif adalah rumusan masalah penelitian yang membandingkan keberadaan satu variabel atau lebih pada dua atau lebih sampel yang berbeda, atau pada waktu yang berbeda" (Sugiyono, 2015:91).Berdasarkan sifatnya, penelitian ini bersifat eksploratif karena pengujian lebih lanjut atas suatu penelitian diperlukan maka penelitian tersebut bersifat eksploratif. Penelitian ini bermaksud menganalisis prediksi penjualan dengan menggunakan data penjualan kredit pada berbagai variasi ukuran bank selama 6 (enam) tahun yaitu tahun 2011 sampai dengan 2016, dengan membandingkan metode prediksi metode semi average, metode product moment dan metode least square.Penelitian ini dilakukan pada Bank Perkreditan Rakyat di Jawa Timur yang dibkelompokkan dalam berbagai variasi ukuran Bank Perkreditan Rakyat yaitu kecil, menengah dan besar. Alasan dipilihnya jenis Bank Perkreditan Rakyat, karena BPR dengan segala keunikannya masih banyak memiliki kelemahan terutama dalam pengelolaan sumber daya nya. Oleh karena itu hasil penelitian ini diharapkan dapat memberikan kontribusi kepada BPR agar dapat melakukan tata kelola bank dengan baik.Data penelitian ini merupakan data internal Bank Perkreditan Rakyat di Indonesia. Sedangkan jenis datanya adalah data sekunder karena data yang diteliti diperoleh dari data yang disajikan oleh Otoritas Jasa Keuangan di Indonesia.Populasi dalam penelitian ini adalah Bank Perkreditan Rakyat di Jawa Timur. Pengambilan sampel dilakukan dengan metode purposive sampling. Kriteria Bank Perkreditan Rakyat yang dapat dijadikan sampel dalam penelitian ini adalah :

a)Bank Perkreditan Rakyat konvensional yang berlokasi di Jawa Timur. b)Bank Perkreditan Rakyat yang sudah berdiri dan terdaftar dalam direktori Bank Indonesia minimal sejak tahun 2008. c)Aktif mempublikasikan laporan keuangannya di direktori Bank Indonesia pada periode 2010 sampai dengan 2017.d) Memiliki informasi lengkap yang diperlukan dalam penelitian yaitu berupa 
Laporan Laba Rugi. BPR yang dijadikan sampel dibagi menjadi 3 (tiga) kategori, yaitu BPR KU 1, BPR KU 2 dan BPR KU 3.Teknik pengumpulan data menggunakan teknik observasi tidak langsung yaitu teknik dokumenter dimana data diperoleh dari catatan peristiwa yang sudah berlalu. Teknik dokumentasi digunakan dengan tipe pooled data yang dimaksudkan agar jumlah observasi memenuhi syarat pengujian OLS (Ordinary Least Square). Data yang diperoleh dilakukan evalusi dengan cara cross sectional approach dan time-series analysis.

\section{Teknik Analisis Data}

Dalam penelitian ini menggunakan teknik komparatif "komparatif adalah penelitian yang bersifat membandingkan. Penelitian ini dilakukan untuk membandingkan persamaan dan perbedaan dua atau lebih fakta dan sifat objek yang diteliti berdasarkan kerangka pemikiran tersebut" (Sugiyono 2013:91).

\section{Metode Prediksi}

\section{Metode Semi Average}

Menentukan trend menurut metode ini tahapannya sebagai berikut :

1)Membagi data deret waktu tersebut menjadi dua kelompok yaitu kelompok I dan kelompok II. Bila jumlah tahunnya genap langsung dibagi dua saja. Bila jumlah tahunnya ganjil, tahun yang tengah dihilangkan atau dimasukkan ke dalam kedua kelompok.2) Mencari rata-rata hitung tiap kelompok ( $\mathrm{X}_{1}$ dan $\mathrm{X}_{2}$ ), rata-rata hitung ini disebut setengah rata-rata dan letakkan pada tahun pertengahan setiap kelompok.3) Nilai setengah rata-rata pada masing-masing kelompok dapat dianggap sebagai nilai trend masing-masing periode.4)Mencari perubahan nilai trend (rata-rata pertambahan atau rata-rata penurunan tiap tahunnya) dengan rumus :

$$
\mathrm{b}=\frac{\overline{\mathrm{X}_{2}}-\overline{\mathrm{X}_{1}}}{\mathrm{n}}
$$

1) Nilai trend pada periode ( tahun ) tertentu bisa dihitung dengan rumus :

$$
\mathbf{Y}^{\prime}=\mathbf{a}+\mathbf{b} \mathbf{X}
$$

\section{Metode Product Moment}

Prediksi penjualan dengan menggunakan metode product moment dilakukan dengan mencari persamaan $\mathrm{Y}=\mathrm{a}+\mathrm{bX}$ dan menggunakan rumus :

$$
\begin{array}{rll|}
\hline \mathrm{Y} & =\mathrm{a}+\mathrm{b}(\mathrm{X}) \\
\text { Persamaan (i) } & : \sum \mathrm{Y} & =\mathrm{n} \cdot \mathrm{a}+\mathrm{b} \cdot \sum \mathrm{X} \\
\text { Persamaan (ii) } & : \sum \mathrm{XY} & =\mathrm{a} \cdot \sum \mathrm{X}+\mathrm{b} \cdot \sum \mathrm{X}^{2}
\end{array}
$$

Sumber : Sri Rahayu Dan Andry Arifian Rachman (2013:35)

Perhitungan dilakukan dengan menentukan model prediksi penjualan menggunakan data penjualan penjualan kredit pada Bank Perkreditan Rakyat di Jawa Timur periode 2010 - 2015. Berdasarkan model prediksi yang terbentuk maka akan digunakan untuk memprediksi penjualan tahun 2014. Langkah-langkah yang dilakukan dalam perhitungan prediksi penjualan menggunakan metode Product Moment sebagai berikut:

a)Menghitung jumlah Y berdasarkan data penjualan kredit tahun 2011 - 2016.b)Menentukan koding $\mathrm{x}$ dengan meletakkan angka 0 pada tahun pertama.c) Memasukkan data jumlah $\mathrm{Y}, \mathrm{x}, \mathrm{X}^{2}$ kedalam rumus persamaan normal.d) Menentukan hasil persamaan $Y=a+$ bx.e) Menentukan prediksi penjualan kredit

\section{Metode Least Square}

Prediksi penjualan dengan menggunakan analisis trend dipergunakan untuk memprediksi ketepatan dalam prediksi penjualan.

Rumus yang digunakan untuk menghitung adalah sebagai berikut :

$\mathrm{Y}=\mathrm{a}+\mathrm{b}(\mathrm{X})$
$\mathrm{a}=\frac{\Sigma \mathrm{Y}}{\mathrm{n}}$
$\mathrm{b}=\frac{\sum \mathrm{\Sigma Y}}{\Sigma \mathrm{X}^{2}}$


Sumber : Lukas Setia Atmaja (2009:32)

Langkah-langkah yang dilakukan dalam perhitungan prediksi penjualan menggunakan metode Least Square sebagai berikut:

a)Menghitung jumlah Y berdasarkan data penjualan kredit tahun 2011 - 2016.b)Menentukan koding $X$.c)Memasukkan data jumlah $Y, X Y, X^{2}$ kedalam rumus .d)Menentukan hasil persamaan $\mathrm{Y}=\mathrm{a}+\mathrm{bx} . \mathrm{e})$ Menentukan prediksi penjualan kredit

\section{Standart Error Of Estimate}

Untuk mengukur ketepatan prediksi dari 3 (tiga) metode ramalan yang diteliti yaitu semi average, product momen dan least square maka digunakan standar error of estimate.

Standart error of estimate (selanjutnya, disebut dengan Sy.x) mengukur dipersi atau simpangan dari data aktual disekitar garis regresi. Jika regresi memberikan Sy.x yang kecil, artinya garis regresi tersebut sangat mewakili data aktual. Jadi Sy.x terutama berguna sebagai indikasi tingkat representative suatu garis regresi. Rumus untuk menghitung Sy.x adalah :

$$
\text { Sy.x }=\sqrt{\frac{\sum\left(\mathrm{Y}-\mathrm{Y}^{\prime}\right)}{\mathrm{n}-2}}
$$

Sumber : Lukas Setia Atmaja (2009:167)

"Standart error of estimate sebagai suatu alat yang sama seperti saat menggunakan deviasi standar. Dengan kata lain, jika diasumikan bahwa $Y$ terdistribusi secara normal, akan mengharapkan bahwa $60 \%$ dari variabel $\mathrm{Y}$ akan terletak pada $\mathrm{Y} \pm$ Sy.x, 95\% dari variabel $\mathrm{Y}$ akan terletak pada $\mathrm{Y} \pm 2$. Sy.x dan 99,7\% dari variabel Y akan terletak pada $Y \pm 3$. Sy.x" (Lukas Setia Atmaja, 2009:167). Analisis hasil dilakukan dengan membandingkan antara hasil perhitungan antara metode semi average, product momen dan least square dengan mempertimbangkan hasil perhitungan standard error of estimate. Selanjutnya akan ditentukan mana diantara ketiga metode tersebut yang mempunyai ketepatan prediksi paling akurat dengan kriteria semakin kecil nilai standard error of estimate, artinya maka semakin akurat hasil prediksi dan sebaliknya semakin besar nilai standard error of estimate, artinya semakin tidak akurat hasil prediksi.

\section{HASIL DAN PEMBAHASAN \\ Hasil Penelitian}

Berdasarkan data yang diperoleh yaitu tentang pendapatan operasional Bank Perkreditan Rakyat untuk periode 2010 sampai dengan 2017, maka dilakukan perhitungan prediksi pendapatan operasional pada masing-masing Bank Perkreditan Rakyat dengan 3 (tiga) metode prediksi yang berbeda dengan tujuan untuk mengetahui model prediksi yang paling mendekati hasil yang tepat. Setiap sampel bank yang diambil akan dihitung dengan menggunakan 3 (tiga) metode prediksi yaitu (1) metode semi average, (2) metode product moment, dan (3) metode least square.

\section{a. Perhitungan Model Persamaan Untuk Prediksi}

Setelah data pendapatan operasional terkumpul maka dilakukan perhitungan untuk menentukan persamaan yang dihasilkan masing-masing metode yang akan digunakan untuk memprediksi pendapatan operasional pada setiap Bank perkreditan Rakyat.

\section{Tabel 1}

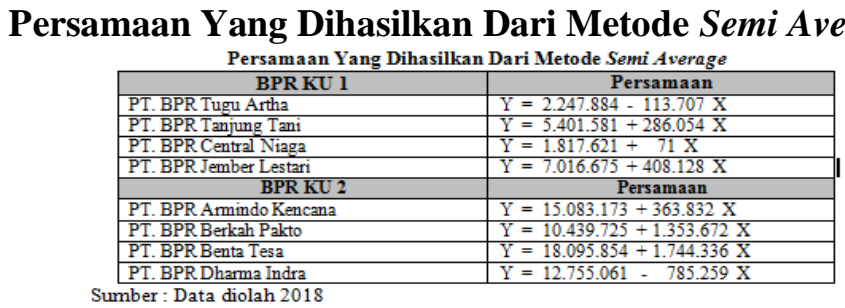

Sumber : Data diolah 2018 
dengan menggunakan metode least square pada PT. BPR Tugu Artha Malang lebih kecil dibandingkan nilai penyimpangan dengan menggunakan model prediksi product moment dan semi avarage.Berdasarkan grafik diatas diketahui bahwa metode yang akurat digunakan untuk memprediksi pendapatan operasional pada PT. BPR Tanjung Tani Kediri adalah metode least square. Hal ini sejalan dengan nilai standar error of estimate yang diperoleh dari perhitungan dengan menggunakan metode least square pada PT. BPR Tanjung Tani Kediri lebih kecil dibandingkan nilai penyimpangan dengan menggunakan model prediksi product moment dan semi avarage.Berdasarkan hasil diatas diketahui bahwa metode yang akurat digunakan untuk memprediksi pendapatan operasional pada PT. BPR Central Niaga Surabaya adalah metode least square. Hal ini sejalan dengan nilai standar error of estimate yang diperoleh dari perhitungan dengan menggunakan metode least square pada PT. BPR Central Niaga Surabaya lebih kecil dibandingkan nilai penyimpangan dengan menggunakan model prediksi product moment dan semi avarage.Berbeda dengan 3 (tiga) BPR dalam kelompok usaha 1 lainnya, berdasarkan hasil diatas diketahui bahwa metode yang akurat digunakan untuk memprediksi pendapatan operasional pada PT. BPR Jember Lestari di Jember adalah metode product moment. Hal ini sejalan dengan nilai standar error of estimate yang diperoleh dari perhitungan dengan menggunakan metode product moment pada PT. BPR Jember Lestari di Jember lebih kecil dibandingkan nilai penyimpangan dengan menggunakan model prediksi least square dan semi avarage.

Berdasarkan penjelasan pada 4 (empat) Bank Perkreditan Rakyat di Jawa Timur yang terpilih sebagai sampel kelompok usaha 1 diatas, maka diperoleh hasil bahwa 3 (tiga) Bank Perkreditan Rakyat yaitu PT. BPR Tugu Artha, PT. BPR Tanjung Tani dan PT. BPR Central Niaga lebih akurat hasil prediksi pendapatan operasionalnya jika menggunakan metode least square. Sedangkan PT. BPR Jember Lestari lebih akurat hasil prediksinya jika menggunakan metode product moment. Oleh karena itu dapat disimpulkan bahwa untuk Bank Perkreditan Rakyat dalam kelompok usaha 1 sebaiknya menggunakan metode least square jika ingin memprediksi pendapatan operasional mereka.Selanjutnya dilakukan pembahasan terhadap hasil prediksi dan membandingkan dengan nilai aktual pendapatan operasional pada Bank Perkreditan Rakyat yang masuk dalam kelompok usaha 2. Hasilnya sebagai berikut:Berdasarkan hasil diatas diketahui bahwa metode yang akurat digunakan untuk memprediksi pendapatan operasional pada PT. BPR Armindo Kencana - Malang adalah metode product moment. Hal ini sejalan dengan nilai standar error of estimate yang diperoleh dari perhitungan dengan menggunakan metode product moment pada PT. BPR Armindo Kencana - Malang lebih kecil dibandingkan nilai penyimpangan dengan menggunakan model prediksi least square dan semi avarage.Berdasarkan hasil diatas diketahui bahwa metode yang akurat digunakan untuk memprediksi pendapatan operasional pada PT. BPR Berkah Pakto Kediri adalah metode product moment. Hal ini sejalan dengan nilai standar error of estimate yang diperoleh dari perhitungan dengan menggunakan metode product moment pada PT. BPR Berkah Pakto Kediri lebih kecil dibandingkan nilai penyimpangan dengan menggunakan model prediksi least square dan semi avarage. Berdasarkan hasil diatas diketahui bahwa metode yang akurat digunakan untuk memprediksi pendapatan operasional pada PT. BPR Benta Tesa Sidoarjo adalah metode product moment. Hal ini sejalan dengan nilai standar error of estimate yang diperoleh dari perhitungan dengan menggunakan metode product moment pada PT. BPR Benta Tesa Sidoarjo lebih kecil dibandingkan nilai penyimpangan dengan menggunakan model prediksi least square dan semi avarage.Berbeda dengan 3 (tiga) BPR dalam kelompok usaha 2 lainnya, berdasarkan hasil diatas diketahui bahwa metode yang akurat digunakan untuk memprediksi pendapatan operasional pada PT. BPR Dharma Indra Lumajang adalah metode least square. Hal ini sejalan dengan nilai standar error of estimate yang diperoleh dari perhitungan dengan menggunakan metode least square pada PT. BPR Dharma Indra Lumajang lebih kecil dibandingkan nilai penyimpangan dengan menggunakan model prediksi product moment dan semi avarage.Berdasarkan penjelasan pada 4 (empat) Bank Perkreditan Rakyat di Jawa Timur yang terpilih sebagai sampel kelompok usaha 2 diatas, maka diperoleh hasil bahwa 3 (tiga) Bank Perkreditan Rakyat yaitu PT. BPR Armindo Kencana Malang, PT> BPR Berkah Pakto Kediri dan PT. BPR Benta Tesa Sidoarjo lebih akurat hasil prediksi pendapatan operasionalnya jika menggunakan metode product moment. Sedangkan PT. BPR Dharma Indra Lumajang lebih akurat hasil prediksinya jika menggunakan metode least square. Oleh karena itu dapat disimpulkan bahwa untuk Bank Perkreditan Rakyat dalam kelompok usaha 2 sebaiknya menggunakan metode product 
moment jika ingin memprediksi pendapatan operasional mereka.Kondisi ini menarik, karena ternyata pada dengan kategori kegiatan usaha yang berbeda yang dibedakan berdasarkan modal intinya, ternyata memberikan hasil yang berbeda dalam hal metode prediksi yang digunakan untuk memprediksi pendapatn operasional pada masing-masing Bank Perkreditan Rakyat. Pada Bank Perkreditan Rakyat kegiatan usaha 1 yaitu dengan modal inti dibawah 15 milyar, maka metode prediksi least square lebih akurat hasil prediksinya dibandingkan dua metode lainnya. Sedangkan pada kelompok Bank Perkreditan Rakyat yang masuk dalam kegiatan usaha 2 yaitu dengan modal inti antara 15 milyar sampai dengan 50 milyar, maka metode prediksi product moment lebih akurat hasil prediksinya dibandingkan dua metode lainnya Oleh karena itu disarankan kepada kelompok Bank Perkreditan Rakyat yang masuk dalam kegiatan usaha 1 untuk lebih menggunakan metode prediksi least square, sedangkan pada Bank Perkreditan Rakyat yang masuk dalam kegiatan usaha 2 untuk lebih menggunakan metode prediksi product moment.

\section{KESIMPULAN}

Berdasarkan hasil penelitian dan pembahasan yang telah diuraikan di atas, maka dapat diambil beberapa kesimpulan sebagai berikut :

a. Metode prediksi pendapatan operasional yang digunakan dalam penelitian ini ada 3 (tiga) yaitu metode semi avarage, metode product moment dan metode least square yang diterapkan pada 2 kelompok Bank Perkreditan Rakyat yaitu kategori kegiatan usaha 1 dengan modal inti dibawah 15 milyar dan kategori kegiatan usaha 2 dengan modal inti antara 15 milyar sampai dengan 50 milyar.

b. Metode prediksi memberikan hasil yang berbeda yaitu pada Bank Perkreditan Rakyat yang masuk dalam kategori kegiatan usaha 1 maka metode prediksi yang akurat digunakan untuk memprediksi pendapatan operasional adalah metode least square, sedangkan kategori kegiatan usaha 2 maka metode prediksi yang akurat digunakan untuk memprediksi pendapatan operasional adalah metode product moment.

c. Secara keseluruhan maka metode least square dan metode product moment merupakan metode yang bisa menjadi pilihan untuk keakuratan prediksi pendapatn operasional pada Bank perkreditan Rakyat

\section{DAFTAR PUSTAKA}

Adisaputro, Gunawan dan Yunita Anggarini. 2011. Anggaran Bisnis. Edisi Kedua. UPP STIM YKPN: Yogyakarta.

Aksoy, Asli and Nursel Ozturk (2012). A Decision Support System For Demand Forecasting In The Clothing Industry.(online). (www.emarald.co.id). 02 maret 2016.

Atmaja, Lukas Setia. 2009. Statistik untuk Bisnis dan Ekonomi. Edisi Pertama. CV. Andi Offset: Yogyakarta.

Fahmi, Irham. 2014. Studi Kelayakan Bisnis Dan Keputusan Investasi. Edisi pertama. Mitra Wacana Media: Jakarta.

Farnoosh, R. P. Nabati and A. Hajirajabi (2012). Parameters Estimation For RL Electrical Circuits Based On Least Square And Bayesian Approach. (online). (www.emarald.co.id). Diaskes 02 maret 2016.

Hakim, Abdul. 2004. Statistik Deskriptif. Edisi Kedua. Bagian Penerbitan Fakultas Ekonomi UII: Yogyakarta.

Paramita, Citra. 2011. Analisis Perbandingan Bahan Minyak Dengan Standar Kesalahan Peramalan (SKP) Pada PT Pertamina (Persero)Region IV Jateng Dan DIY. Skripsi. (Online). (https://scholar.google.co.id). Diaskes 02 Maret 2016.

Prawironegoro. Darsono dan Ari Purwanto. 2010. Penganggaran Perusahaan. Edisi Kedua. Mitra Wacana Media: Jakarta.

Rahayu, Sri dan Andry Arifian Rachman. 2013. Penyusunan Anggaran. Edisi Pertama. Graha Ilmu: Yogyakarta.

Sugiyono. 2015. Metode Penelitian Manajemen. Edisi Empat. CV. Alfabeta: Bandung. 